\title{
PENGARUH PROSES REKRUTMEN DAN KOMPETENSI TERHADAP KINERJA KARYAWAN PADA PT FIF GROUP POS BAYUNG LENCIR
}

Yeni Marsih

marsihyeni@gmail.com

Ika Rakhmalina

Ika.rakhmalina1983@gmail.com

\section{Sekolah Tinggi Ilmu Ekonomi Rahmaniyah Sekayu}

\begin{abstract}
ABSTRAK
Penelitian ini bertujuan untuk mengetahui pengaruh proses rekrutmen dan kompetensi terhadap kinerja karyawan pada PT FIF Group Pos Bayung Lencir. Adapun metode penelitian yang digunakan Penulis dalam penelitian ini adalah metode kuantitatif. Jenis dan sumber data yang digunakan Penulis pada penelitian ini adalah data primer. Dalam penelitian ini Penulis menggunakan aplikasi SPSS versi 26. Hasil perhitungan statistik secara parsial untuk variabel proses rekrutmen dapat kita lihat bahwa nilai $t$ hitung $>$ dari nilai $t$ tabel, yakni 3,531>2,008 dan untuk variabel kompetensi dapat kita lihat bahwa nilai thitung $>$ dari nilai t tabel, yakni 3,905 >2,008. Pengujian pengaruh variabel bebas secara simultan menggunakan uji $F$ diperoleh nilai $F$ hitung sebesar 15,938 > dari nilai $F$ tabel yaitu 4,03. Jadi dapat disimpulkan bahwa proses rekrutmen dan kompetensi berpengaruh terhadap kinerja karyawan baik secara parsial maupun simultan pada PT FIF Group Pos Bayung Lencir.
\end{abstract}

\section{Kata kunci: Rekrutment, Kompetensi, Kinerja}

\subsection{Latar Belakang Masalah}

Pengelolaan Sumber Daya Manusia (SDM) merupakan hal yang penting dalam pencapaiaan tujuan. Umumnya pimpinan perusahaan mengharapkan kinerja yang baik dari masing-masing karyawan dalam mengerjakan tugas-tugas yang diberikan oleh perusahaan. Perusahaan menyadari bahwa Sumber Daya Manusia (SDM) merupakan modal dasar dalam proses pembangunan perusahaan bahkan nasional, oleh karena itu kualitas SDM senantiasa harus dikembangkan dan diarahkan agar tercapainya tujuan yang telah ditetapkan oleh perusahaan.

Perkembangan perusahaan dalam memenuhi kebutuhan konsumen yang bervariasi mengharuskan perusahaan untuk mempunyai karyawan yang berprestasi tinggi. Salah satu cara yang dapat digunakan untuk menilai perkembangan perusahaan adalah dengan cara melihat hasil penilaian kinerja.

Menurut Robbin (2015: 104), kinerja merupakan hasil kerja secara kualitas dan kuantitas yang dicapai oleh seseorang dalam melaksanakan fungsinya sesuai dengan tanggungjawab yang diberikan kepadanya. Beberapa faktor yang mempenyaruhi kinerja karyawan adalah proses rekrutmen karyawan dan kompetensi yang dimiliki oleh karyawan itu sendiri. Handoko (2016: 92), menjelaskan bahwa rekrutmen merupakan proses pencarian dan "pemikatan" para calon karyawan (pelamar) yang mampu untuk melamar sebagai karyawan. Sedangkan kompetensi yang dinyatakan oleh Wibowo (2014: 271), adalah suatu kemampuan untuk melaksanakan atau melakukan suatu pekerjaan atau tugas yang dilandasi atas keterampilan dan pengetahuan serta didukung oleh sikap kinerja yang dituntut oleh pekerjaan tersebut. 
Tabel 1.1

PT. FIF Pos Bayung Lencir

Jumlah Karyawan dan Karyawan Masuk/Karyawan Keluar

\begin{tabular}{|c|c|c|c|c|c|c|c|c|c|}
\hline \multirow{2}{*}{ No } & Tahun & $\begin{array}{c}\text { Karyawan } \\
\text { Masuk } \\
\text { (Awal } \\
\text { Tahun) }\end{array}$ & $\begin{array}{c}\text { Karyawan } \\
\text { Keluar }\end{array}$ & $\begin{array}{c}\text { Kumlah } \\
\text { Karyawan } \\
\text { (Akhir } \\
\text { Tahun) }\end{array}$ & \multicolumn{2}{|c|}{$\begin{array}{c}\text { Jenis } \\
\text { Kelamin }\end{array}$} & \multicolumn{4}{|c|}{ UR } & LK & $18-28$ & $29-38$ & $>38$ \\
\hline 1 & 2014 & 12 & 8 & 40 & 18 & 22 & 12 & 13 & 15 \\
\hline 2 & 2015 & 7 & 9 & 38 & 17 & 21 & 11 & 12 & 14 \\
\hline 3 & 2016 & 13 & 10 & 41 & 18 & 23 & 12 & 13 & 16 \\
\hline 4 & 2017 & 14 & 5 & 50 & 23 & 27 & 15 & 16 & 19 \\
\hline 5 & 2018 & 8 & 10 & 48 & 22 & 26 & 14 & 15 & 18 \\
\hline 6 & 2019 & 20 & 13 & 55 & 25 & 30 & 17 & 18 & 20 \\
\hline 7 & 2020 & 7 & 2 & 60 & 28 & 32 & 18 & 20 & 22 \\
\hline
\end{tabular}

Sumber: PT. FIF Pos Bayung Lencir, 2021, data diolah

Dari Tabel 1.1 diatas menunjukan terjadi pergerakan yang cukup fluktuatif pada jumlah karyawan masuk dan jumlah karyawan yang keluar pada PT. FIF Pos Bayung Lencir, tinginya tingkat turnover. Hal ini menunjukkan bahwa terjadi kesalahan dalam proses rekurtmen yaitu karyawan yang direkrut tidak mempunyai keinginan yang kuat untuk bekerja diperusahaan, atau tidak mempunyai rasa sebagai bagian atau rasa memiliki perusahaan. Tinginya tingkat turnover pada PT. FIF Pos Bayung Lencir memaksa perusahaan melakukan rekrutmen, demi memenuhi ketersediaan karyawan.

Fenomena lain dalam proses rekrutmen PT. FIF Group Pos Bayung Lencir adalah masih banyaknya calon pelamar yang memasukkan surat lamaran tetapi tidak sesuai dengan persyaratan yang telah ditentukan oleh perusahaan, misalnya kualifikasi pendidikan yang tidak sesuai (persyaratan miniman D3/S1 tetapi masih banyak pelamar SMA), jurusan yang berbeda dan IPK tidak sesuai dengan ketentuan. Hal ini menyebabkan manajemen harus sangat teliti dalam memilih data calon pelamar yang benar-benar memiliki kemampuan dan keahlian sesuai dengan yang diharapkan perusahaan untuk mengikuti tes tahap selanjutnya.

Fenomena tentang kompetensi karyawan pada PT. FIF Group Pos Bayung Lencir yaitu terlihat dari karyawan di tingkat pelaksana/staf kurang mengusai subtansi pekerjaanya, dimana penyelesaian tugas-tugas hanya ditangani oleh beberapa karyawan saja baik secara individu maupun tim, sehingga tugas-tugas cenderung terkonsentrasi pada mereka saja yang dinilai memiliki kompetensi dalam hal kemampuan, keterampilan dan kecakapan, sementara sebagian lainnya bekerja seadanya tanpa pola dan sasaran yang jelas.

Berdasarkan uraian di atas, maka dapat disimpulkan bahwa terjadi fenomena dalam proses rekrutmen di PT FIF Group Pos Bayung Lencir, dimana perusahaan salah pilih calon karyawan yang mengakibatkan menjadi karyawan yang kurang kompeten, hal ini berdampak pada kinerja karyawan tersebut kurang maksimal.

Berdasakan uraian diatas maka penulis tertarik untuk melakukan penelitian dengan judul : Pengaruh Proses Rekrutmen dan Kompetensi Terhadap Kinerja Karyawan Pada PT FIF Group Pos Bayung Lencir.

\subsection{Rumusan Masalah}

Berdasarkan latar belakang tersebut, maka penulis mengidentifikasi masalah adalah Bagaimana pengaruh proses rekrutmen dan kompetensi terhadap kinerja karyawan pada PT FIF Group Pos Bayung Lencir? 


\subsection{Tujuan Penelitian}

Berdasarkan rumusan masalah diatas, maka penelitian ini bertujuan untuk mengetahui pengaruh proses rekrutmen dan kompetensi terhadap kinerja karyawan pada PT FIF Group Pos Bayung Lencir.

\subsection{Metodologi Penelitian}

\subsubsection{Lokasi dan Waktu Penelitian}

Dalam setiap penelitian yang dilakukan perlu sekali adanya objek penelitian begitu juga dengan penelitian ini, yang menjadi objek dalam penelitian ini adalah PT FIF Pos Bayung Lencir yang dijadikan objek dalam penelitian yang berlokasi di Jalan PalembangJambi KM 203 Srimaju RT 12 RW 001 Kelurahan Bayung Lencir Kecamatan Bayung Lencir Kabupaten Musi Banyuasin. Waktu dalam penelitian ini selama 3 (tiga) bulan.

\subsubsection{Desain Penelitian}

Dalam penelitian ini Penulis menggunakan desain penelitian kausalitas. Sanusi (2017: 13), menyatakan desain penelitian kausalitas adalah desain penelitian yang disusun untuk meneliti kemungkinan adanya hubungan sebab-akibat antar variabel. Dalam desain ini, umumnya hubungan sebab akibat tersebut sudah dapat diprediksi oleh peneliti sehingga peneliti dapat menyatakan klasifikasi variabel penyebab, variabel antara dan variabel terikat. Pengujian terhadap hubungan sebab akibat antar variabel yang banyak diterapkan adalah teknik-teknik statistik inferensial.

\subsubsection{Jenis dan Sumber Data}

Adapun jenis dan sumber data yang digunakan Penulis pada penelitian ini adalah data primer. Data primer yang digunakan oleh Penulis pada penelitian ini adalah data dari hasil kuesioner dan wawancara.

\subsubsection{Teknik Pengumpulan Data}

Adapun teknik pengumpulan data yang digunakan oleh Penulis adalah kuesioner, wawancara dan studi pustaka.

\subsubsection{Operasional Variabel}

Tabel 1.2

Definisi Operasional

\begin{tabular}{|c|c|c|c|c|}
\hline Variabel & Definisi Variabel & Indikator & $\begin{array}{c}\text { Nomor } \\
\text { Pertayaan }\end{array}$ & $\begin{array}{c}\text { Skala } \\
\text { ukur }\end{array}$ \\
\hline $\begin{array}{l}\text { Proses } \\
\text { Rekrutmen } \\
\left(\mathrm{X}^{1}\right)\end{array}$ & $\begin{array}{l}\text { Handoko (2016: } 92) \text {, } \\
\text { menjelaskan bahwa rekrutmen } \\
\text { merupakan proses pencarian } \\
\text { dan "pemikatan" para calon } \\
\text { karyawan (pelamar) yang } \\
\text { mampu untuk melamar sebagai } \\
\text { karyawan. }\end{array}$ & $\begin{array}{l}\text { 1. Analisis Jabatan } \\
\text { 2. Uraian Jabatan } \\
\text { 3. Persyaratan Jabatan } \\
\text { 4. Penilaian Jabatan } \\
\text { 5. Penggolongan } \\
\text { Jabatan }\end{array}$ & $\begin{array}{c}1-2 \\
3-4 \\
5-6 \\
7-8 \\
9-10\end{array}$ & Ordinal \\
\hline $\begin{array}{c}\text { Kompetensi } \\
\left(\mathrm{X}^{2}\right)\end{array}$ & $\begin{array}{l}\text { Menurut Wibowo (2014: 271), } \\
\text { kompetensi adalah suatu } \\
\text { kemampuan untuk } \\
\text { melaksanakan atau melakukan } \\
\text { suatu pekerjaan atau tugas yang } \\
\text { dilandasi atas keterampilan dan } \\
\text { pengetahuan serta didukung } \\
\text { oleh sikap kinerja yang dituntut } \\
\text { oleh pekerjaan tersebut. }\end{array}$ & $\begin{array}{l}\text { 1. Motif } \\
\text { 2. Sifat } \\
\text { 3. Konsep diri } \\
\text { 4. Pengetahuan } \\
\text { 5. Keterampilan }\end{array}$ & $\begin{array}{c}1-2 \\
3-4 \\
5-6 \\
7-8 \\
9-10\end{array}$ & Ordinal \\
\hline $\begin{array}{l}\text { Kinerja } \\
\text { karyawan } \\
(\mathrm{Y})\end{array}$ & $\begin{array}{l}\text { Menurut Robbin (2015: 104), } \\
\text { kinerja merupakan hasil kerja } \\
\text { secara kualitas dan kuantitas }\end{array}$ & $\begin{array}{l}\text { 1. Kualitas kinerja } \\
\text { 2. Efisiensi waktu } \\
\text { kerja }\end{array}$ & $\begin{array}{l}1-2 \\
3-4 \\
5-6\end{array}$ & Ordinal \\
\hline
\end{tabular}




\begin{tabular}{|l|l|l|c|c|}
\hline & $\begin{array}{l}\text { yang dicapai oleh seseorang } \\
\text { dalam melaksanakan fungsinya } \\
\text { sesuai dengan tanggungjawab } \\
\text { yang diberikan kepadanya. }\end{array}$ & $\begin{array}{l}\text { 3. Kemampuan } \\
\text { pegawai } \\
\text { 4. Efektivitas } \\
\text { penyelesaiaan tugas } \\
\text { 5. Komitmen Kerja }\end{array}$ & $9-10$ & $7-8$ \\
\hline
\end{tabular}

\subsubsection{Skala Pengukuran}

Adapun skala pengukuran yang digunakan Penulis dalam penelitian ini adalah skalaordinal. Sugiyono(2016: 128), menyatakan skala ordinal ialah skala pengukuran yang sifatnya membedakan dan mengurutkan. Skala ordinal adalah suatu skala psikometrik yang umum digunakan dalam kuesioner, dan merupakan skala yang paling banyak digunakan dalam riset berupa survei. Dalam penentuan skor ini digunakan skala ordinal dengan lima kategori penilaian, yaitu :

a. $\mathrm{SS}=$ sangat setuju dengan skor 5

b. $\mathrm{S}=$ setuju dengan skor 4

c. $\mathrm{N}=$ netral dengan skor 3

d. TS = tidak setuju dengan Skor 2

e. STS = sangat tidak setuju dengan skor 1

\subsubsection{Instrumen Penelitian}

Dalam penelitian ini Penulis menggunakan kuesioner sebagai instrumen penelitian.

\subsubsection{Populasi dan Sampel}

Dalam penelitian ini yang menjadi populasi adalah seluruh tetap PT FIF Pos Bayung Lencir berjumlah 60 karyawan terdiri 15 karyawan tetap dan 45 karywan tidak tetap. Dari populasi tersebut, maka diambil sampel dengan menggunakan rumus Slovin.

Rumus :

$$
\mathrm{N}=\frac{\mathrm{N}}{1+\mathrm{N}\left(\mathrm{d}^{2}\right)}
$$

\section{Keterangan :}

$\mathrm{n}=$ Ukuran sampel

$\mathrm{N}=$ Ukuran populasi

$\mathrm{d}=$ Tingkat kepercayaan yang diinginkan $(0,05)$

$$
\mathrm{N}=\frac{60}{1+60\left(0,05^{2}\right)}
$$

$$
\mathrm{N}=\frac{60}{1,15}
$$

$\mathrm{n}=52$ Responden

\subsubsection{Teknik Pengelolaan Data dan Teknik Analisis Data \\ 1.4.9.1 Teknik Pengelolaan Data}

Sebelum melakukan analisis data, maka perlu dilakukan tahap-tahap teknik pengolahan data sebagai berikut :

\section{Editing}

Editing merupakan proses pengecekan dan penyesuaian yang diperoleh terhadap data penelitian untuk memudahkan proses pemberian kode dan pemprosesan data dengan teknik statistik. 
2. Coding

Coding merupakan kegiatan pemberian tanda berupa angka pada jawaban dari kuesioner untuk kemudian dikelompokkan ke dalam kategori yang sama. Tujuannya adalah menyederhanakan jawaban.

3. Scoring

Scoring yaitu mengubah data yang bersifat kualitatif kedalam bentuk kuantitatif. Dalam penentuan skor ini digunakan skala likert dengan lima kategori penilaian, yaitu:

a. SS = sangat setuju dengan skor 5

b. $\mathrm{S}=$ setuju dengan skor 4

c. $\mathrm{N}=$ netral dengan skor 3

d. $\mathrm{TS}=$ tidak setuju dengan Skor 2

e. STS = sangat tidak setuju dengan skor 1

4. Tabulating

Tabulating yaitu menyajikan data-data yang diperoleh dalam tabel, sehingga diharapkan pembaca dapat melihat hasil penelitian dengan jelas. Setelah proses tabulating selesai dilakukan, kemudian diolah dengan program komputer SPSS (Statistical Product and service) versi 26.00 .

\subsubsection{Teknik Analisis Data}

Pada penelitian ini, Penulis menggunakan teknik analisis kuantitaif. Adapun teknik analisis kuantitaif yang digunakan penulis pada penelitian ini adalah dengan melakukan pengujian hipotesis. Pengujian ini digunakan untuk mengetahui apakah variabel independen mempengaruhi secara signifikan terhadap variabel dependen.

\subsection{Uji Validitas}

Untuk mengukur validitas tidaknya setiap faktor dapat dilakukan dengan cara mengkorelasikan skor faktor tertentu dengan skor total, dengan menggunakan korelasi product moment dengan angka dasar yang dikemukakan oleh Pearson, sebagai berikut :

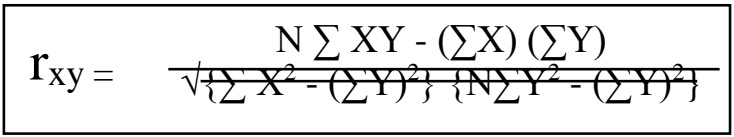

Dimana :

$\mathrm{r}_{\mathrm{xy}}=$ Validitas instrumen

$\mathrm{X}=$ Jumlah skor faktor tertentu

$\mathrm{Y}=$ Jumlah skor total

Menurut Priyatno (2016: 17), uji validitas dilakukan dengan membandingkan nilai $r$ hitung dengan $r$ tabel untuk tingkat signifikansi 5 persen dari degree of freedom $(\mathrm{df})=\mathrm{n}-2$, dalam hal ini $n$ adalah jumlah sampel. Jika $r$ hitung $>r$ tabel maka pertanyaan atau indikator tersebut dinyatakan valid, demikian sebaliknya bila $r$ hitung $<r$ tabel maka pertanyaan atau indikator tersebut dinyatakan tidak valid.

\subsection{Uji Reliabilitas}

Priyatno (2016: 25), menyatakan uji reliabilitas merupakan alat untuk mengukur suatu kuesioner yang merupakan indikator dari variabel atau konstruk. Suatu kuesioner dikatakan reliabel atau handal jika jawaban seseorang terhadap pernyataan adalah konsisten atau stabil dari waktu ke waktu. Pengukuran reliabilitas dilakukan dengan cara one shot atau pengukuran sekali saja dengan alat bantu SPSS uji statistik Cronbach Alpha ( $\alpha)$. Untuk pengambilan keputusan uji reabilitas bisa menggunakan batasan 0.6. Reabilitas kurang dari 0.6 adalah kurang baik, sedangkan 0.7 dapat diterima dan diatas 0.8 adalah baik. 


\subsubsection{Uji Asumsi Klasik}

1. Uji Multikolinearitas

Uji multikolinearitas adalah untuk menguji apakah pada model regresi ditemukan adanya korelasi antar variabel bebas (independen). Apabila terjadi korelasi, maka dinamakan terdapat problem multikolinearitas. Model regresi yang baik seharusnya tidak terjadi korelasi diantara variabel bebas.

2. Uji Heteroskedastisitas

Uji heteroskedastisitas adalah untuk menguji apakah dalam model regresi terjadi ketidaksamaan varians dari residual satu pengamatan ke pengamatan yang lain. Jika varians dari residual satu pengamatan ke pengamatan lain tetap, maka disebut homoskedastisitas dan jika varians berbeda disebut heteroskedstisitas. Model regresi yang baik adalah yang homokedastisitas atau tidak terjadi heteroskedastisitas.

3. Uji Normalitas

Uji normalitas digunakan untuk menguji apakah dalam model regresi, kedua variabel (bebas maupun terikat) mempunyai distribusi normal atau setidaknya mendekati normal. Pada prinsipnya normalitas dapat dideteksi dengan melihat penyebaran data (titik) pada sumbu diagonal dari grafik atau dengan melihat histogram dari residualnya.

\subsubsection{Analisis Regresi Linier Berganda}

Analisis ini digunakan untuk mengetahui seberapa besar pengaruh variabel bebas yaitu : proses rekrutmen $\left(\mathrm{X}^{1}\right)$ dan kompetensi $\left(\mathrm{X}^{2}\right)$ terhadap variabel terikatnya yaitu kinerja karyawan (Y). Sunyoto (2017: 110), menyatakan persamaan regresi linier sederhana adalah sebagai berikut :

$\mathbf{Y}=\mathbf{a}+\mathbf{b} \mathbf{X}^{\mathbf{1}}+\mathbf{b} \mathbf{X}^{\mathbf{2}}$

Keterangan :

$\mathrm{Y}=$ Variabel dependen (kinerja karyawan)

$\mathrm{a}=$ Konstanta

$\mathrm{b}=$ Koefisien garis regresi

$\mathrm{X}^{1}=$ Variaber independen (proses rekrutmen)

$\mathrm{X}^{2}=$ Kompetensi (proses rekrutmen)

\subsubsection{Pengujian Hipotesis}

\section{Uji Korelasi (R)}

Sugiyono (2016: 78), menyatakan pedoman untuk memberikan intepretasi koefisien korelasi sebagai berikut:

Koefisien Korelasi

\begin{tabular}{|c|c|}
\hline Koefisien Korelasi & Kriteria \\
\hline $0,00-0,199$ & Sangat Rendah \\
$0,20-0,399$ & Rendah \\
$0,40-0,599$ & Sedang \\
$0,60-0,799$ & Kuat \\
$0,80-1,000$ & Sangat Kuat \\
\hline
\end{tabular}

Sumber : Sugiyono (2016: 78)

2 Koefisien Determinasi $\left(\mathrm{R}^{2}\right)$

Kuncoro (2016: 220), menyatakan koefesien determinasi mengukur seberapa jauh kemampuan model dalam menerangkan variasi variabel dependennya. Nilai koefesien determinasi adalah antara nol dan satu nilai $\mathrm{R}^{2}$ yang kecil berarti kemampuan variabel-variabel indenpendent dalam menjelaskan variasi variabel dependen sangat terbatas dan nilai yang mendekati satu berarti variabel-variabel independen memberikan 
hampir semua informasi yang dibutuhkan untuk memprediksi variasi variabel dependentnya.

1. Uji Signifikasi Pengaruh Parsial (Uji t)

Uji t digunakan untuk menguji signifikansi hubungan antara variabel $\mathrm{X}$ dan $\mathrm{Y}$, apakah variabel $\mathrm{X}^{1}$ (proses rekrutmen) dan $\mathrm{X}^{2}$ (kompetensi) benar-benar berpengaruh terhadap variabel Y (kinerja karyawan) secara terpisah atau parsial Priyatno (2016: 61). Hipotesis yang digunakan dalam pengujian ini adalah:

Ho1 : Proses rekrutmen tidak berpengaruh terhadap kinerja karyawan pada PT FIF Pos Bayung Lencir

Ha1 : Proses rekrutmen berpengaruh terhadap kinerja karyawan pada PT FIF Pos Bayung Lencir

Ho2: Kompetensi tidak berpengaruh terhadap kinerja karyawan pada PT FIF Pos Bayung Lencir

Ha2 : Kompetensi berpengaruh terhadap kinerja karyawan pada PT FIF Pos Bayung Lencir

Dasar pengambilan keputusan Priyatno (2016: 61), adalah dengan menggunakan angka probabilitas signifikansi yaitu :

a. Apabila angka probabilitas signifikansi > 0,05, maka Ho diterima dan Ha ditolak.

b. Apabila angka probabilitas signifikansi $<0,05$, maka Ho ditolak dan Ha diterima.

4. Uji Signifikansi Simultan (Uji Statistik F)

Dalam penelitian ini, uji $\mathrm{F}$ digunakan untuk mengetahui tingkat siginifikansi pengaruh variabel-variabel independen secara bersama-sama (simultan) terhadap variabel dependen Priyatno (2016: 81), dalam penelitian ini, hipotesis yang digunakan adalah :

Ho3 : Proses rekrutmen dan kompetensi tidak berpengaruh yang signifikan terhadap kinerja karyawan pada PT FIF Pos Bayung Lencir

Ha3 : Proses rekrutmen dan kompetensi berpengaruh yang signifikan terhadap kinerja karyawan pada PT FIF Pos Bayung Lencir

Dasar pengambilan keputusannya adalah dengan menggunakan angka probabilitas signifikansi, yaitu :

a. Apabila probabilitas signifikansi $>0.05$, maka Ho diterima dan Ha ditolak.

b. Apabila probabilitas signifikansi < 0.05 , maka Ho ditolak dan Ha diterima.

\subsection{Landasan Teori}

\subsubsection{Konsep Rekrutmen}

\subsubsection{Pengertian Rekrutmen}

Handoko (2016: 92), menjelaskan bahwa rekrutmen merupakan proses pencarian dan "pemikatan" para calon karyawan (pelamar) yang mampu untuk melamar sebagai karyawan. Rekrutmen sebagai suatu rangkaian kegiatan yang dimulai ketika sebuah perusahaan memerlukan tenaga kerja dan membuka lowongan sampai mendapatkan calon yang diinginkan atau memenuhi kualifikasi sesuai dengan jabatan atau lowongan yang ada.

\subsubsection{Sumber-sumber Rekrutmen}

Malthis (2017: 93), menyebutkan rekrutmen dalam pelaksanaannya tidak terlepas dari sumber internal dan eksternal organisasi. Sumber internal cukup menetukan dalam rekrutmen karena terkait dengan political will dan motif-motif perusahaan. Sedangkan sumber eksternal yang berkaitan dengan rekrutmen adalah kondisi politik, sosial, ekonomi, bahkan hukum.

1. Rekrutmen Internal

Cara umum yang digunakan oleh perusahaan adalah:

a. Meminta bantuan karyawan lama 
Salah satu cara yang umum digunakan oleh perusahaan untuk mencari calon karyawan adalah dengan meminta bantuan dari karyawan lama, yaitu mereka yang sudah ada di dalam perusahaan.

b. Mencari dari arsip

Hampir setiap perusahaan selalu menerima lamaran dari orang yang mencari pekerjaan biasanya hampir $99 \%$ dari orang muda yang belum pernah bekerja karena baru lulus sekolah atau universitas.

c. Mengumumkan secara terbuka didalam perusahaan

Walaupun perusahaan telah mempunyai kebijakan dan aturan bahwa setiap lowongan akan diberikan kesempatan lebih dulu kepada karyawan yang sudah ada untuk melamar, semua persyaratan harus diumumkan secara terbuka

2. Rekrutmen Eksternal

Cara yang umun digunakan oleh perusahaan:

a. Pelamar langsung dan referensi

Pelamar datang langsung pada organisasi meskipun organisasi tidak membuat publikasi adanya lowongan pekerjaan. Referensi pelamar direkomendasikan oleh orang atau karyawan dari dalam kepada departemen personalia.

b. Iklan

Tujuan utama dari iklan lowongan kerja adalah memberitahukan bahwa disuatu perusahaan ada lowongan kerja dan mengundang mereka yang merasa berminat dan memenuhi syarat yang ditetapkan untuk melamar atau menawarkan diri untuk mengisinya. Karena itu lowongan kerja mengandung unsur undangan, bukan hanya sekedar pemberitahuan.

c. Agensi Tenaga kerja Pemerintah

Agen-agen tenaga kerja yang dikelola oleh pemerintah biasanya informasinya mudah dijangkau oleh masyarakat yang membutuhkan pekerjaan, terutama yang bersifat tidak terampil. Kantor tenaga kerja akan menginformasikan kepada pencari kerja apabila terdapat lowongan kerja yang tidak cocok.

d. Agen Tenaga Kerja Swasta

Keberadaannya terbatas dikota-kota besar yang diselenggarakan oleh konsultant dan lembaga dan informasi sumber daya manusia.

e. Sewa (Leasing)

Tehnik ini biasa digunakan organisasi yang ingin melakukan penghematan dari segi anggaran sumber daya manusia.

f. Open house

Tehnik ini lebih kepada organisasi yang ingin menarik calon pelamar yang memiliki keterampilan dan kemampuan yang langka dan terbatas.

g. Nepotisme

Pemeberian jabatan kepada keluarga yang biasanya bisa lebih dipercaya dalam pengerjaan tugas.

h. Lembaga pendidikan dan universitas

Rekrutmen dari sekolah-sekolah dan universitas bisa dilakukan dengan cara menjalin kerjasama dengan lembaga tersebut.

i. Perekrutan elektronik

Metode perekrutan melalui internet ini merupakan metode yang dirasa paling efisien bagi perusahaan. 


\subsubsection{Tujuan Rekrutmen}

Handoko (2016: 134), mengemukakan bahwa tujuan rekrutmen adalah untuk memenuhi penawaran sebanyak mungkin dari calon-calon karyawan sehingga organisasi memilik peluang yang lebih besar untuk menentukan pilihan terhadap calon pelamar yang dianggap memenuhi standar kualifikasi organisasi.

\subsubsection{Prinsip-Prinsip Rekrutmen}

Handoko (2016: 139), menjelaskan ada beberapa prinsip yang harus di perhatikan pada proses rekrutmen:

a. Mutu karyawan yang akan direkrut harus sesuai dengan kebutuhan yang diperlukan untuk mendapatkan mutu yang sesuai.

b. Jumlah karyawan yang diperlukan harus sesuai dengan job yang tersedia, yang perlu dilakukan:

1. Peramalan kebutuhan tenaga kerja

2. Analisis terhadap kebutuhan tenaga kerja (work force analysis)

a) Biaya yang diperlukan diminimalkan

b) Perencanaan dan keputusan-keputusan yang strategis tentang perekrutan

c) Fleksibility

d) Pertimbangan-Pertimbangan hukum.

\subsubsection{Kendala-kendala Dalam Proses Rekrutmen}

Kusdyah (2016: 85), menyatakan kendala-kendala dalam proses rekrutmen antara lain

1. Karakteristik Organsasi

Karakteritistik organisasi tercermin dari sistem nilai, norma, dan budaya perusahaan, filosofi oganisasi, visi dan misi organisasi, serta tujuan dan strategi organisasi.

2. Tujuan dan kebijakan organisasi

Tujuan organisasi adalah ingin mencapai penggunaan sumber daya yang efektif dan efisiensi.

3. Kondisi lingkungan eksternal

Kondisi lingkuungan akan mempengaruhi nasib organisasi secara keseluruhan.

4. Biaya rekrutmen

Masalah biaya dapat menjadi kendala tersendiri bagi organisasi yang ingin memperbarui tenaga kerja karena tuntutan pekerjaan.

5. Kompensasi

Kompensasi ini bisa bertindak sebagai perangsang atau insentif untuk menarik calon tenaga kerja.

6. Kebiasaan perekrutan

Kebiasaan perekrutan yang biasa dilakukan dianggap baku dan dilakukan secara berulangulang, padahal tidak semua perekruta merupakan kegiatan yang paling efektif, maka para pelaksana perekrutan hendaknya menerima masukan yang positif maupun negatif agar tidak bergantung pada kebiasaan yang buruk yang sudah terbentuk.

\subsubsection{Sikap Dalam Rekrutmen}

Nawawi (2017: 92), mengemukakan terdapat 4 (empat) sikap yang berbeda di lingkungan organisasi/perusahaan dalam melakukan rekrutmen. Keempat sikap tersebut adalah :

1. Sikap pasif tanpa diskriminasi, sikap ini merupakan sikap para eksekutif di lingkungan organisasi/perusahaan untuk meniadakan perbedaan dan memberlakukan secara sama dalam mengangkat, menggaji dan memberikan promosi bagi para calon dan para pekerja.

2. Rekrutmen berdasarkan perbedaan, rekrutmen ini dilakukan secara aktif untuk mengelompokkan para pelamar, dengan hanya menerima kelompok tertentu. 
3. Rekrutmen berdasarkan prioritas, rekrutmen ini dilakukan dengan mendahulukan atau memprioritaskan kelompok tertentu.

4. Rekrutmen dengan penjatahan, rekrutmen ini dilakukan dengan menetapkan jatah untuk kelompok tertentu.

\subsubsection{Penentuan Dasar Rekrutmen}

Menurut Hasibuan (2016: 127), dasar penarikan calon karyawan harus ditetapkan lebih dahulu supaya para pelamar yang akan memasukkan lamarannya sesuai dengan pekerjaan atau jabatan yang diminatinya. Dasar penarikan harus berpedoman pada spesifikasi pekerjaan yang telah ditentukan untuk menduduki jabatan tersebut. Job Specification harus diuraikan secara terperinci dan jelas agar para pelamar mengetahui kualifikasi yang dituntut oleh lowongan kerja tersebut. Jika spesifikasi pekerjaan dijadikan dasar dan pedoman penarikan, maka karyawan yang diterima akan sesuai dengan uraian pekerjaan dari jabatan yang diperlukan oleh perusahaan.

Setelah diketahui spesifikasi jabatan atau pekerjaan karyawan yang diperlukan, maka harus ditentukan sumber-sumber penarikan calon karyawan. Sumber penarikan calon karyawan bisa berasal dari internal dan eksternal perusahaan.

1. Sumber Internal

Sumber internal adalah karyawan yang akan mengisi lowongan kerja yang diambil dari dalam perusahaan tersebut. Adapun kebaikan dari sumber internal yaitu :

a. Tidak terlalu mahal

b. Dapat memelihara loyalitas dan mendorong motivasi karyawan yang ada.

c. Karyawan telah terbiasa dengan suasana dan budaya perusahaan.

Sedangkan kelemahan dari sumber internal yaitu :

a. Pembatasan terhadap bakat-bakat.

b. Mengurangi peluang

c. Dapat meningkatkan perasaan puas diri.

Adapun sumber-sumber internal antara lain melalui :

a. Penawaran terbuka untuk suatu jabatan (Job Posting Program).

Rekrutmen terbuka ini merupakan sistem mencari pekerja yang memiliki kemampuan tinggi untuk mengisi jabatan yang kosong dengan memberikan kesempatan kepada semua karyawan yang berminat.

b. Perbantuan pekerja (Departing Employees)

Rekrutmen ini dapat dilakukan melalui perbantuan pekerja untuk suatu jabatan dari unit kerja lain.

2. Sumber Eksternal

Sumber-sumber ekternal berasal dari :

a. Kantor penempatan tenaga kerja

b. Lembaga-lembaga pendidikan

c. Referensi karyawan atau rekan

d. Serikat-serikat buruh

e. Pencangkokan dari perusahaan lain

f. Nepotisme atau leasing

g. Pasar tenaga kerja dengan memasang iklan pada media massa.

h. Sumber-sumber lainnya.

\subsubsection{Indikator Rekrutmen}

Handoko (2016: 139), menjelaskan indikator yaitu job analisys, job description, job spesification, job evalution, job clasivication, dengan uraian sebagai berikut:

1. Analisis Jabatan (Job Analysis) 
Analisis jabatan merupakan suatu cara mendasar dalam manajemen sumber daya manusia untuk mendapatkan suatu posisi jabatan, kemudian menyalurkannya ke dalam format untuk memudahkan memahami secara akurat informasi tentang jabatan dalam organisasi, serta merancang program dan kegiatan penataan jabatan.

2. Uraian Jabatan (Job Description)

Uraian pekerjaan/uraian jabatan adalah suatu proses mengumpulkan, mengkategorikan, dan mendokumentasikan seluruh informasi yang relevan tentang jabatan tersebut dalam periode tertentu.

3. Persyaratan Jabatan (Job Spesification)

Persyaratan perkerjaan adalah catatan mengenai syarat-syarat orang yang minimum harus dimiliki untuk menyelesaikan suatu perjaan dengan baik

4. Penilaian Jabatan (Job Evalution)

Penilaian jabatan adalah kegiatan yang dilakukan guna membandingkan nilai dari suatu jabatan dengan nilai dari jabatan lainnya

5. Penggolongan Jabatan (Job Classification)

Penggolongan jabatan adalah pengelompokan jabatan-jabatan yang memiliki nilai yang sama.

\subsubsection{Konsep Kompetensi}

\subsubsection{Pengertian Kompetensi}

Menurut Wibowo (2014: 271), kompetensi adalah suatu kemampuan untuk melaksanakan atau melakukan suatu pekerjaan atau tugas yang dilandasi atas keterampilan dan pengetahuan serta didukung oleh sikap kinerja yang dituntut oleh pekerjaan tersebut.

\subsubsection{Faktor-faktor yang Mempengaruhi Kompetensi}

Wibowo (2014: 283 ), menyebutkan faktor-faktor yang mempengaruhi kompetensi antara lain :

1) Keyakinan dan nilai-nilai

Keyakinan orang tentang dirinya maupun terhadap orang lain akan sangat mempengaruhi perilaku.

2 ) Keterampilan

Pengembangan keterampilan yang secara spesifik berkaitan dengan kompetensi dapat berdampak baik pada budaya organisasi dan kompetensi individual.

3 ) Pengalaman

Keahlian dari banyak kompetensi memerlukan pengalaman mengorganisasi orang, komunikasi dihadapan kelompok, menyelesaiakan masalah dan sebagainya.

4 ) Karakteristik kepribadian

Kepribadian dapat mempengaruhi keahlian manajer dan pekerja dalam sejumlah kompetensi, termasuk dalam penyelesaian konflik, menunjukkan kepedulian interpersonal, kemampuan bekerja dalam tim, memberikan pengaruh dan membangun hubungan.

5) Motivasi

Dengan memberikan dorongan, apresiasi terhadap pekerjaan bawahan, memberikan pengakuan dan perhatian individual dari atasan dapat mempunyai pengaruh positif terhadap motivasi seseorang bawahan.

6) Isu emosional

Hambatan emosional dapat membatasi penguasaan kompetensi .

7) Kemampuan intelektual

Kompetensi tergantung pada pemikiran kognitif seperti pemikiran konseptual dan pemikiran analitis.

8) Budaya organisasi 
Budaya organisasi mempengaruhi kompetensi sumber daya manusia dalam kegiatan praktik rekrutmen dan seleksi karyawan, sistem penghargaan, praktik pengambilan keputusan, filosofi organisasi, misi, visi dan nilai-nilai, kebiasaan dan prosedur, komitmen pada pelatihan dan pengembangan pada pekerja, dan proses organisasional .

\subsubsection{Indikator Kompetensi}

Wibowo (2014: 273), menyebutkan terdapat lima indikator kompetensi antara lain sebagai berikut :

1) Motif

Motif adalah sesuatu yang secara konsisten dipikirkan atau diinginkan orang yang menyebabkan tindakan.

2 ) Sifat

Sifat adalah karakteristik fisik dan respons yang konsisten terhadap situasi atau informasi .

3 ) Konsep diri

Konsep diri adalah sikap, nilai-nilai, atau citra diri seseorang.

4 ) Pengetahuan

Pengetahuan adalah informasi yang dimiliki orang dalam bidang spesifik .

5 ) Keterampilan

Keterampilan adalah kemampuan mengerjakan tugas fisik atau mental tertentu.

\subsubsection{Konsep Kinerja Karyawan}

\subsubsection{Pengertian Kinerja Karyawan}

Robbin (2015: 104), menyatakan kinerja merupakan hasil kerja secara kualitas dan kuantitas yang dicapai oleh seseorang dalam melaksanakan fungsinya sesuai dengan tanggungjawab yang diberikan kepadanya. Suatu organisasi, baik itu pemerintah maupun swasta, selalu digerakan oleh sekelompok orang yang berperan aktif untuk mencapai tujuan yang ingin dicapai dari organisasi tersebut. Tujuan organisasi tentunya tidak akan tercapai jika kinerja anggota atau pegawainya tidak maksimal.

\subsubsection{Faktor-faktor yang Mempengaruhi Kinerja Pegawai}

Terdapat beberapa pendapat yang mengenai faktor-faktor yang mempengaruhi kinerja pegawai. Robbin (2015: 216), menyatakan kinerja pegawai dipengaruhi oleh beberapa faktor, yaitu :

1. Kualitas Pekerjaan (Quality of Work)

Merupakan tingkat baik atau buruknya sesuatu pekerjaan yang diterima bagi seorang pegawai yang dapat dilihat dari segi ketelitian dan kerapihan kerja, keterampilan dan kecakapan.

2. Kuantitas Pekerjaan (Quantity of Work)

Merupakan seberapa besarnya beban kerja atau sejumlah pekerjaan yang harus diselesaikan oleh seorang pegawai.

3. Pengetahuan Pekerjaan (Job Knowledge)

Merupakan proses penempatan seorang pegawai yang sesuai dengan background pendidikan atau keahlian dalam suatu pekerjaan.

4. Kerjasama Tim (Teamwork)

Melihat bagaimana seorang pegawai bekerja dengan orang lain dalam menyelesaikan suatu pekerjaan.

5. Kreatifitas (Creativity)

Merupakan kemampuan seorang pegawai dalam menyelesaikan pekerjaannya dengan cara atau inisiatif sendiri yang dianggap mampu secara efektif dan efisien serta mampu menciptakan perubahan-perubahan baru guna perbaikan dan kemajuan organisasi.

6. Inovasi (Inovation) 
Kemampuan menciptakan perubahan-perubahan baru guna perbaikan dan kemajuan organisasi.

7. Inisiatif (Initiative)

Melingkupi beberapa aspek seperti kemampuan untuk mengambil langkah yang tepat dalam menghadapi kesulitan, kemampuan untuk melakukan sesuatu pekerjaan tanpa bantuan, kemampuan untuk mengambil tahapan pertama dalam kegiatan.

Pasolong (2015: 216), menyatakan pengukuran kinerja pegawai penting dilakukan oleh instansi pelayanan publik. Dengan mengetahui kelemahan dan kelebihan, hambatan dan dorongan, atau berbagai faktor sukses bagi kinerja pegawai serta institusi maka terbukalah jalan menuju profesionalisasi, yaitu memperbaiki kesalahan-kesalahan yang dilakukan selama ini.

\subsubsection{Indikator Kinerja Karyawan}

Robbin (2015: 104), menyatakan bahwa kinerja dapat dikatakan baik bila karyawan memenuhi hal sebagai berikut :

1. Kualitas kerja, diukur dari persepsi karyawan terhadap kualitas pekerjaan yang dihasilkan serta kesempurnaan tugas terhadap keterampilan dan kemampuan karyawan.

2. Efisiensi waktu kerja, diukur dari persepsi pegawai terhadap suatu aktivitas yang diselesaikan dari awal waktu sampai menjadi output.

3. Kemampuan pegawai, tingkat dimana karyawan dapat melakukan fungsi kerjanya tanpa meminta bantuan atau bimbingan dari orang lain, diukur dari persepsi karyawan dalam melakukan fungsi kerjanya masing-masing sesuai dengan tanggung jawabnya.

4. Efektivitas penyelesaian tugas, persepsi karyawan dalam menilai pemanfaatan waktu dalam menjalankan tugas, efektivitas penyelesaian tugas dibebankan organisasi.

5. Komitmen kerja, tingkat dimana karyawan mempunyai komitmen kerja dengan instansi dan tanggung jawab karyawan terhadap kantor.

\subsubsection{Teori Hubungan Antar Variabel}

\subsubsection{Teori Hubungan Proses Rekrutment terhadap Kinerja Karyawan}

Yusmaniarti (2018), menyebutkan hubungan proses rekrutmen karyawan dengan kinerja pada sesuatu perusahaan tampaknya amat bergantung pada unsur manajemen dari perusahaan tersebut. Oleh karena itu yang perlu mendapatkan sorotan adalah unsur manajemen itu, apakah diterapkan dengan baik atau sebaliknya. Dalam upaya mencapai tujuan perusahaan, proses rekrutmen mempunyai peran yang sangat penting karena para karyawan yang direkrut itulah nanti yang akan menggerakkan seluruh aspirasi dan merealisasikan tujuan perusahaan secara administrasi dan operasional. Kinerja yang baik dan berkualitas boleh dicapai melalui proses perekrutan karyawan yang baik dan menepati segala prosedur dan teknik rekrutmen. Karena itulah proses rekrutmen karyawan boleh dikatakan sangat berpengaruh terhadap kinerja.

\subsubsection{Teori Hubungan Kompetensi terhadap Kinerja Karyawan}

Rosento (2018), menyebutkan dalam rumusan standar kompetensi tentang kemampuan dan kinerja yang harus dicapai, diantaranya meliputi :

1. Apa yang diharapkan dapat dikerjakan oleh seseorang.

2. Seberapa jauh kinerja yang diharapkan tersebut dapat dicapai seseorang.

3. Bagaimana mengukur/membuktikan bahwa seseorang telah mencapai kinerja yang diharapkan.

Kompetensi dapat juga digunakan sebagai kreteria untuk menentukan penempatan kerja karyawan. Karyawan yang ditempatkan pada tugas tertentu akan mengetahui kompetensi apa yang diperlukan, serta jalan yang harus ditempuh untuk mencapainya dengan mengevaluasi kompetensi-kompetensi yang sesuai dengan tolak ukur penilaian kinerja. Sehingga sistem pengelolaan Sumber Daya Manusia (SDM) lebih terarah, karyawan dapat 
dikembangkan untuk meningkatkan pengetahuan, ketrampilan, keahlian, tingkat kompetensi dan kinerjanya. Pentingnya kompetensi dalam meningkatkan kinerja karyawan mempunyai hubungan yang sangat kuat, peningkatan kinerja ini tergantung dengan kompetensi yang dimiliki satu individu. Kompetensi Sumber Daya Manusia seperti pengetahuan dan kemampuan modal utama bagi karyawan untuk mencapai tujuan dan harapan yang dikehandaki tujuan karyawan.

\subsection{Penelitian Terdahulu}

\begin{tabular}{|c|c|c|c|c|c|c|c|}
\hline No & $\begin{array}{c}\text { Nama } \\
\text { Peneliti }\end{array}$ & $\begin{array}{c}\text { Judul } \\
\text { Penelitian }\end{array}$ & $\begin{array}{l}\text { Variabel } \\
\text { Penelitian }\end{array}$ & $\begin{array}{l}\text { Metodologi } \\
\text { Penelitian }\end{array}$ & Indikator Penelitian & $\begin{array}{c}\text { Hasil } \\
\text { Penelitian }\end{array}$ & $\begin{array}{l}\text { Perbedaan } \\
\text { Penelitian }\end{array}$ \\
\hline 1 & $\begin{array}{c}\text { Dewa } \\
\text { Sukma } \\
\text { Sari } \\
(2019)\end{array}$ & $\begin{array}{l}\text { Pengaruh } \\
\text { Rekrutmen } \\
\text { Terhadap } \\
\text { Kinerja } \\
\text { Karyawan } \\
\text { Pada PT } \\
\text { Guthrie } \\
\text { Pecconina } \\
\text { Indonesia }\end{array}$ & $\begin{array}{l}\text { Variabel } \\
\text { dependen : } \\
\text { Rekrutmen } \\
\text { Variabel } \\
\text { independen } \\
: \quad \text { Kinerja } \\
\text { Karyawan }\end{array}$ & Kuantitatif & $\begin{array}{l}\text { Variabel dependen : } \\
\text { 1. Dasar sumber } \\
\text { perekrutan } \\
\text { pegawai } \\
\text { 2. Sumber pegawai } \\
\text { 3. Metode perekrutan } \\
\text { pegawai } \\
\text { Variabel independen: } \\
\text { 1. Kualitas kinerja } \\
\text { 2. Efisiensi waktu } \\
\text { kerja } \\
\text { 3. Kemampuan } \\
\text { pegawai } \\
\text { 4. Efektivitas } \\
\text { penyelesaiaan } \\
\text { tugas } \\
\text { 5. Komitmen Kerja }\end{array}$ & $\begin{array}{l}\text { Rekrutmen } \\
\text { berpengaruh } \\
\text { terhadap } \\
\text { kinerja } \\
\text { karyawan } \\
\text { pada PT } \\
\text { Guthrie } \\
\text { Pecconina } \\
\text { Indonesia }\end{array}$ & $\begin{array}{l}\text { Lokasi, } \\
\text { Tahun, } \\
\text { Variabel } \\
\text { Penelitian }\end{array}$ \\
\hline 2 & $\begin{array}{c}\text { Julian } \\
\text { Ashariandi } \\
(2017)\end{array}$ & $\begin{array}{l}\text { Pengaruh } \\
\text { Kompetensi } \\
\text { dan } \\
\text { Motivasi } \\
\text { Karyawan } \\
\text { Terhadap } \\
\text { Kinerja Pada } \\
\text { Departemen } \\
\text { Perencanaan } \\
\text { Material dan } \\
\text { Pergudangan } \\
\text { PT. Pusri } \\
\text { Palembang }\end{array}$ & $\begin{array}{l}\text { Variabel } \\
\text { dependen : } \\
\text { Kompetensi } \\
\text { dan } \\
\text { Motivasi } \\
\text { Variabel } \\
\text { independen } \\
: \quad \text { Kinerja } \\
\text { Karyawan }\end{array}$ & Kuantitatif & $\begin{array}{l}\text { Variabel dependen : } \\
\text { Kompetensi } \\
\text { 1. Motif } \\
\text { 2. Sifat } \\
\text { 3. Konsep diri } \\
\text { 4. Pengetahuan } \\
\text { 5. Keterampilan } \\
\text { Motivasi } \\
\text { 1. Fisiologis } \\
\text { 2. Penghargaan } \\
\text { 3. Aktualisasi Diri } \\
\text { Variabel independen: } \\
\text { 1. Kuantitas } \\
\text { 2. Kualitas } \\
\text { 3. Waktu }\end{array}$ & $\begin{array}{l}\text { Kompetensi } \\
\text { dan motivasi } \\
\text { karyawan } \\
\text { berpengaruh } \\
\text { baik secafrfa } \\
\text { simultan } \\
\text { maupun } \\
\text { parsial } \\
\text { terhadap } \\
\text { kinerja pada } \\
\text { departemen } \\
\text { perencanaan } \\
\text { material dan } \\
\text { pergudangan } \\
\text { PT. Pusri } \\
\text { Palembang }\end{array}$ & $\begin{array}{l}\text { Lokasi, } \\
\text { Tahun, } \\
\text { Variabel } \\
\text { Penelitian }\end{array}$ \\
\hline
\end{tabular}




\subsection{Kerangka Pemikiran}

\begin{tabular}{|c|c|}
\hline \multicolumn{2}{|l|}{ Proses Rekrutmen $\left(\mathrm{X}^{1}\right)$} \\
\hline \multirow{2}{*}{\multicolumn{2}{|c|}{$\begin{array}{l}\text { 1. Analisis Jabatan } \\
\text { 2. Uraian Jabatan }\end{array}$}} \\
\hline & \\
\hline 3. Persyaratan Jabatan & Kinerta Karvawan $(V)$ \\
\hline Kompetensi $\left(\mathrm{X}^{2}\right)$ & $\begin{array}{l}\text { 1. Kualitas kinerja } \\
\text { 2.Efisiensi waktu keria }\end{array}$ \\
\hline $\begin{array}{l}\text { 1) Motif } \\
\text { 2) Sifat } \\
\text { 3 ) Konsep diri }\end{array}$ & $\begin{array}{l}\text { 4.Efektivitas penyelesaiaan tugas } \\
\text { 5.Komitmen Kerja } \\
\text { Sumber: Robbin (2015: 104) }\end{array}$ \\
\hline 5 ) Keterampilan & \\
\hline Sumber: Wibowo (2014: 273) & 4 \\
\hline
\end{tabular}

\subsection{Hipotesis}

Arikunto (2015: 68), menyatakan hipotesis adalah jawaban yang bersifat sementara terhadap permasalahan penelitian sampai terbukti melalui data. Berdasarkan landasan teori dan kerangka berpikir di atas, hipotesis pada penelitian ini dapat dirumuskan adalah proses rekrutmen dan kompetensi berpengaruh terhadap kinerja karyawan pada PT FIF Pos Bayung Lencir.

\subsection{Hasil Penelitian}

\subsubsection{Analisis Data}

\subsubsection{Pengujian Validitas}

\begin{tabular}{|c|c|c|c|c|}
\hline No. & Variabel/Indikator & r hitung & r tabel & Keterangan \\
\hline & Proses rekrutmen & & & \\
\hline 1 & Item 1 & 0,498 & 0,2732 & valid \\
\hline 2 & Item 2 & 0,491 & 0,2732 & valid \\
\hline 3 & Item 3 & 0,571 & 0,2732 & valid \\
\hline 4 & Item 4 & 0,667 & 0,2732 & valid \\
\hline 5 & Item 5 & 0,490 & 0,2732 & valid \\
\hline 6 & Item6 & 0,427 & 0,2732 & valid \\
\hline 7 & Item7 & 0,417 & 0,2732 & valid \\
\hline 8 & Item8 & 0,563 & 0,2732 & valid \\
\hline 9 & Item9 & 0,669 & 0,2732 & valid \\
\hline 10 & Item10 & 0,462 & 0,2732 & valid \\
\hline No. & Variabel/Indikator & r hitung & r tabel & Keterangan \\
\hline & Kompetensi & & & \\
\hline 1 & Item 1 & 0,401 & 0,2732 & valid \\
\hline 2 & Item 2 & 0,482 & 0,2732 & valid \\
\hline 3 & Item 3 & 0,589 & 0,2732 & valid \\
\hline 4 & Item 4 & 0,315 & 0,2732 & valid \\
\hline 5 & Item 5 & 0,608 & 0,2732 & valid \\
\hline 6 & Item6 & 0,458 & 0,2732 & valid \\
\hline
\end{tabular}




\begin{tabular}{|c|c|c|c|c|}
\hline 7 & Item7 & 0,439 & 0,2732 & valid \\
\hline 8 & Item8 & 0,405 & 0,2732 & valid \\
\hline 9 & Item9 & 0,526 & 0,2732 & valid \\
\hline 10 & Item10 & 0,414 & 0,2732 & valid \\
\hline & Kinerja Karyawan & & & \\
\hline 1 & Item 1 & 0,333 & 0,2732 & valid \\
\hline 2 & Item 2 & 0,532 & 0,2732 & valid \\
\hline 3 & Item 3 & 0,490 & 0,2732 & valid \\
\hline 4 & Item 4 & 0,600 & 0,2732 & valid \\
\hline 5 & Item 5 & 0,411 & 0,2732 & valid \\
\hline 6 & Item6 & 0,425 & 0,2732 & valid \\
\hline 7 & Item7 & 0,576 & 0,2732 & valid \\
\hline 8 & Item8 & 0,534 & 0,2732 & valid \\
\hline 9 & Item9 & 0,316 & 0,2732 & valid \\
\hline 10 & Item10 & 0,665 & 0,2732 & valid \\
\hline
\end{tabular}

\subsubsection{Pengujian Reliabilitas}

\begin{tabular}{|c|c|c|}
\hline Variabel & Alpha & Keterangan \\
\hline Proses rekrutmen & 0,725 & Reliabel \\
Kompetensi & 0,698 & Reliabel \\
Kinerja Karyawan & 0,709 & Reliabel \\
\hline
\end{tabular}

\subsubsection{Uji Asumsi Klasik}

\subsection{Uji Multikolinieritas}

\begin{tabular}{|l|l|r|r|}
\hline \multicolumn{4}{|c|}{ Coefficients $^{\mathbf{a}}$} \\
\hline \multirow{4}{*}{ Model } & \multicolumn{1}{|c|}{ Collinearity Statistics } \\
\cline { 3 - 4 } & Tolerance & VIF \\
\hline 1 & Proses Rekrutmen &, 729 & 1,371 \\
\cline { 2 - 4 } & Komptensi &, 729 & 1,371 \\
\hline \multicolumn{2}{|l|}{ a. Dependent Variable: Kinerja Karyawan } \\
\hline
\end{tabular}

\subsection{Uji Heteroskedastisitas}

\begin{tabular}{|c|c|c|c|c|c|c|}
\hline \multicolumn{7}{|c|}{ Coefficients $^{a}$} \\
\hline \multirow{2}{*}{\multicolumn{2}{|c|}{ Model }} & \multicolumn{2}{|c|}{$\begin{array}{l}\text { Unstandardized } \\
\text { Coefficients }\end{array}$} & $\begin{array}{l}\text { Standardized } \\
\text { Coefficients }\end{array}$ & \multirow[b]{2}{*}{$t$} & \multirow[b]{2}{*}{ Sig. } \\
\hline & & $\mathrm{B}$ & Std. Error & Beta & & \\
\hline 1 & (Constant) &,- 024 & 3,275 & &,- 007 & ,994 \\
\hline & Proses Rekrutmen & ,205 & 084 & ,386 & 2,447 & 018 \\
\hline & Komptensi &,- 128 & ,103 &,- 196 & $-1,238$ & 222 \\
\hline
\end{tabular}

\subsection{Uji Normalitas Data}

\begin{tabular}{|l|l|r|}
\hline \multicolumn{2}{|c|}{ One-Sample Kolmogorov-Smirnov Test } \\
\hline \multicolumn{2}{|c|}{} & $\begin{array}{c}\text { Unstandardized } \\
\text { Residual }\end{array}$ \\
\hline N & Mean & 52 \\
\cline { 2 - 3 } Normal Parameters & Stb &, 0000000 \\
\hline \multirow{2}{*}{ Most Extreme Differences } & Absolute & 4,59092800 \\
\cline { 2 - 3 } & Positive &, 108 \\
\cline { 2 - 3 } & Negative &,- 105 \\
\hline
\end{tabular}




\begin{tabular}{|l|r|}
\hline Test Statistic &, 108 \\
\hline Asymp. Sig. (2-tailed) &, $189^{\mathrm{c}}$ \\
\hline a. Test distribution is Normal. \\
\hline b. Calculated from data. \\
\hline \multicolumn{2}{|l}{ c. Lilliefors Significance Correction. } \\
\hline
\end{tabular}

\subsection{Uji Autokorelasi}

\begin{tabular}{|c|c|c|c|c|c|}
\hline \multicolumn{6}{|c|}{ Model Summary } \\
\hline Model & $\mathrm{R}$ & R Square & $\begin{array}{l}\text { Adjusted R } \\
\text { Square }\end{array}$ & $\begin{array}{l}\text { Std. Error of the } \\
\text { Estimate }\end{array}$ & Durbin-Watson \\
\hline 1 & $449^{a}$ & ,201 &, 169 & 4,684 & 1,726 \\
\hline
\end{tabular}

\subsection{Pembahasan}

Berdasarkan estimasi regresi berganda dengan program SPSS versi 26.00 diperoleh hasil seperti tabel berikut ini:

\begin{tabular}{|c|c|c|c|c|c|c|}
\hline \multicolumn{7}{|c|}{ Coefficients $^{a}$} \\
\hline \multirow{2}{*}{\multicolumn{2}{|c|}{ Model }} & \multicolumn{2}{|c|}{$\begin{array}{l}\text { Unstandardized } \\
\text { Coefficients }\end{array}$} & \multirow{2}{*}{$\begin{array}{c}\begin{array}{c}\text { Standardized } \\
\text { Coefficients }\end{array} \\
\text { Beta } \\
\end{array}$} & \multirow[b]{2}{*}{$t$} & \multirow[b]{2}{*}{ Sig. } \\
\hline & & $B$ & Std. Error & & & \\
\hline 1 & (Constant) & 18,578 & 5,187 & & 3,582 &, 001 \\
\hline & Proses Rekrutmen & ,203 &, 133 & ,229 & 3,531 & ,001 \\
\hline & Komptensi & ,312 & , 164 & ,285 & 3,905 & ,001 \\
\hline
\end{tabular}

\section{Sumber : Data primer yang diolah, 2021}

Berdasarkan tabel dapat diketahui persamaan regresi yang terbentuk adalah :

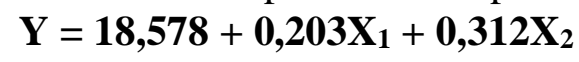

Dari persamaan tersebut dapat dijelaskan bahwa :

1. Variabel proses rekrutmen dan kompetensi mempunyai arah koefisien yang bertanda positif terhadap kinerja karyawan pada PT FIF Group Pos Bayung Lencir.

2. Koefisien proses rekrutmen memberikan nilai sebesar 0,203 yang berarti bahwa jika proses rekrutmen semakin tinggi dengan asumsi variabel lain tetap maka kinerja karyawan PT FIF Group Pos Bayung Lencir akan mengalami peningkatan.

3. Koefisien kompetensi memberikan nilai sebesar 0,312 yang berarti bahwa jika proses rekrutmen semakin baik dengan asumsi variabel lain tetap maka kinerja karyawan PT FIF Group Pos Bayung Lencir akan mengalami peningkatan.

Berdasarkan Tabel di atas dapat dilihat bahwa $\mathrm{t}$ hitung untuk variabel proses rekrutmen sebesar 3,531 dan t hitung untuk variabel kompetensi sebesar 3,905. Untuk mengetahui pengaruh proses rekrutmen dan kompetensi terhadap kinerja karyawan secara parsial dengan menggunakan $t$ hitung, maka kita harus membandingkan antara $t$ hitung dan $t$ tabel. Apabila t hitung $>\mathrm{t}$ tabel, maka variabel proses rekrutmen dan kompetensi berpengaruh terhadap kinerja karyawan. Untuk mengetahui nilai $\mathrm{t}$ tabel, maka dapat digunakan persamaaan sebagai berikut: $\mathrm{Df}=\mathrm{n}-2$, di mana $\mathrm{n}$ merupakan dua sudut pandang. Jadi $\mathrm{df}=52$ $2=50$. Jadi dapat kita lihat pada tabel t pada df 50 yaitu sebesar 2,008.

Perbandingan $t$ hitung dan $t$ tabel untuk variabel proses rekrutmen dapat kita lihat bahwa nilai t hitung $>$ dari nilai t tabel, yakni 3,531>2,008. Jadi berdasarkan perbandingan nilai t hitung dan $\mathrm{t}$ tabel, dapat disimpulkan bahwa variabel proses rekrutmen berpengaruh terhadap kinerja karyawan pada PT FIF Group Pos Bayung Lencir.

Perbandingan $t$ hitung dan $t$ tabel untuk variabel kompetensi dapat kita lihat bahwa nilai t hitung $>$ dari nilai t tabel, yakni 3,905 >2,008. Jadi berdasarkan perbandingan nilai $t$ 
hitung dan t tabel, dapat disimpulkan bahwa variabel kompetensi berpengaruh terhadap kinerja karyawan pada PT FIF Group Pos Bayung Lencir.

Berdasarkan tingkat signifikansi, apabila tingkat signifikansi berada dibawah atau lebih kecil dari 5\%, maka variabel tersebut berpengaruh terhadap variabel dependent dan begitupula sebaliknya. Dari hasil penelitian diperoleh tingkat signifikansi sebesar 0,001. Jadi dapat dikatakan bahwa tingkat signifikansi variabel proses rekrutmen dan kompetensi berada dibawah standar, artinya variabel proses rekrutmen dan kompetensi secara parsial memiliki pengaruh terhadap kinerja karyawan pada PT FIF Group Pos Bayung Lencir

Pengujian pengaruh variabel bebas secara bersama-sama terhadap variabel terikatnya dilakukan dengan menggunakan uji F. Hasil perhitungan statistik menunjukkan nilai F hitung $=6,174$. Dengan menggunakan batas signifikansi 0,05, maka diperoleh nilai $\mathrm{F}$ hitung 15,938 $>$ dari 4,03. Maka Ho ditolak dan menerima Ha. Hal ini berarti bahwa hipotesis yang menyatakan bahwa secara simultan variabel proses rekrutmen dan kompetensi secara parsial memiliki pengaruh terhadap kinerja karyawan pada PT FIF Group Pos Bayung Lencir.

\subsection{Implementasi Penelitian}

Berdasarkan hasil penelitian dan pengujian baik secara parsial maupun simultan variabel proses rekrutmen dan kompetensi memiliki pengaruh terhadap kinerja karyawan pada PT FIF Group Pos Bayung Lencir. Hasil penelitian ini juga sejalan dengan penelitian yang dilakukan Dewa (2019) yang berjudul Pengaruh Rekrutment terhadap Kinerja Karyawan pada PT. Guthrie Peconina Indonesia. Hasil penelitian menyatakan perbandingan t hitung dan $t$ tabel dapat kita lihat bahwa nilai t hitung > dari nilai t tabel, yakni 5,455 > 0,197. Dari hasil perbandingan nilai t hitung dan $t$ tabel, dapat disimpulkan bahwa variabel proses rekrutment berpengaruh terhadap kinerja karyawan PT Guthrie Pecconina Indonesia.

\subsection{Simpulan}

Hasil dari uji validitas reliabilitas menunjukkan bahwa seluruh pernyataan dalam setiap variabel reliabel dan valid. Dalam uji asumsi klasik menunjukkan bahwa dalam model regresi tidak ditemukan adanya korelasi antar variabel bebas dan tidak terjadi heteroskedastisitas serta memiliki distribusi normal serta adanya tidak terjadinya autokorelasi.

Dari pembahasan yang telah diuraikan, maka dapat ditarik simpulan sebagai berikut :

1. Pengujian regresi berganda menunjukkan bahwa variabel proses rekrutmen dan kompetensi mempunyai arah koefisien yang bertanda positif terhadap kinerja karyawan pada PT FIF Group Pos Bayung Lencir.

2. Pengujian korelasi menunjukkan bahwa terjadi hubungan yang rendah antara proses rekrutmen terhadap kinerja karyawan PT FIF Group Pos Bayung Lencir. Hal ini dikarenakan nilai $\mathrm{R}$ berada diantara 0,20 sampai dengan 0,399 dengan intepretasi koefisien kolerasi rendah serta terjadi hubungan yang sedang antara kompetensi dengan kinerja karyawan PT FIF Group Pos Bayung Lencir. Hal ini karena nilai R berada diantara 0,40 sampai dengan 0,599 dengan intepretasi koefisien kolerasi sedang.

3. Koefisien determinasi (adjusted $R^{2}$ ) yang diperoleh sebesar 0,687. Hal ini berarti $68,70 \%$ variasi variabel kinerja karyawan PT FIF Group Pos Bayung Lencir dapat dijelaskan oleh variabel proses rekrutmen dan kompetensi sedangkan sisanya sebesar 32,30\% diterangkan oleh variabel lain yang tidak dianalisis dalam penelitian ini seperti kemampuan kerja, lingkungan kerja, budaya organisasi dan lain sebagainya.

4. Perbandingan $t$ hitung dan $t$ tabel untuk variabel proses rekrutmen dapat kita lihat bahwa nilai t hitung > dari nilai t tabel, yakni 3,531>2,008. Jadi berdasarkan perbandingan nilai $t$ 
hitung dan t tabel, dapat disimpulkan bahwa variabel proses rekrutmen berpengaruh terhadap kinerja karyawan pada PT FIF Group Pos Bayung Lencir.

5. Perbandingan $t$ hitung dan $t$ tabel untuk variabel kompetensi dapat kita lihat bahwa nilai $t$ hitung > dari nilai t tabel, yakni 3,905 >2,008. Jadi berdasarkan perbandingan nilai $t$ hitung dan t tabel, dapat disimpulkan bahwa variabel kompetensi berpengaruh terhadap kinerja karyawan pada PT FIF Group Pos Bayung Lencir.

6. Pengujian pengaruh variabel bebas secara bersama-sama terhadap variabel terikatnya dilakukan dengan menggunakan uji $\mathrm{F}$. Hasil perhitungan statistik menunjukkan nilai $\mathrm{F}$ hitung $=6,174$. Dengan menggunakan batas signifikansi 0,05 , maka diperoleh nilai $\mathrm{F}$ hitung 15,938 > dari 4,03. Maka Ho ditolak dan menerima Ha.

\subsection{Saran}

Berdasarkan simpulan yang telah dilakukan maka saran yang dapat diberikan dalam penelitian ini yaitu :

Bagi PT FIF Group Pos Bayung Lencir hendaknya dalam meningkatkan kinerja karyawan lebih menitik beratkan pada kompetensi kerja, dilihat dari kuesioner yang telah diisi oleh karyawan PT FIF Group Pos Bayung Lencir tersebut diperoleh data bahwa karyawan memiliki kompetensi yang tinggi pada pekerjaan yang mereka laksanakan, sehingga dengan keorganisasian lebih mekompetensi karyawannya misalnya dengan pemberian penghargaan terhadap karyawan yang berprestasi atau kenaikan jabatan akan dapat meningkatkan kinerja karyawan yang lebih baik lagi.

\section{DAFTAR PUSTAKA}

Arikunto, Suharsimi. 2015. Prosedur Penelitian Suatu Pendekatan, Edisi Revisi. Yogyakarta:Rhineka Cipta.

Ashariandi, Julian. 2017. Pengaruh Kompetensi dan Motivasi Karyawan Terhadap Kinerja Pada Departemen Perencanaan Material dan Pergudangan PT. Pusri Palembang. Skripsi. Universitas Muhammadiyah Pelembang

Handoko T. Hani, 2016. Manajemen Personalia dan Sumber Daya Manusia. Yogyakarta: BPFE.

Hasibuan, Malayu, SP. 2016. Manajemen Sumber Daya Manusia. Jakarta: Bumi Aksara

Kusdyah, Ike, R. 2016. Manajemen Sumber Daya Manusia. Yogyakarta: CV Andi Offset

Malthis, Robert. L. 2017. Manajemen Sumber Daya manusia. Jakarta: Salemba Empat.

Nasir, Moh. 2016. Metode Penelitian, Jakarta: Ghalia Indonesia.

Nawawi, Hadari. 2017. Manajemen Sumber Daya Manusia Untuk Bisnis yang Kompetitif. Yogyakarta: Gadjah Mada University Press.

Pasolong, Harbani. 2015. Teori Administrasi Publik. Bandung: CV. Alfabeta

Robbin, P. Stephen. 2015. Perilaku Organisasi. Jakarta: PT Prinhalindo

Rosento. 2018. Analisis Hubungan Kompetensi Terhadap Kinerja Karyawan. Jurnal Kompetensi

Siagian, Sondang P. 2015. Manajemen Sumber Daya Manusia. Jakarta: Bumi Aksara.

Sugiyono. 2016. Metode Penelitian Kuantitatif Kualitatif Dan R\&D. Bandung: Alfabeta

Sukma, Dewa Sari. 2019. Pengaruh Rekrutmen Terhadap Kinerja Karyawan Pada PT Guthrie Pecconina Indonesia. Skripsi. Sekolah Tinggi Ilmu Ekonomi Rahmaniyah Sekayu

Sunyoto, Danang. 2017. Metode Penelitian Untuk Bisnis. Yogyakarta: CAPS

Wibowo. 2014. Manajemen Kinerja. Jakarta: P T Rajagrafindo Persada 
JURNAL MANAJEMEN KOMPETEN

Vol. 4 No.1 Juli 2021, 43-62

Yusmaniarti. 2018. Pengaruh Rekrutmen Karyawan Terhadap Kinerja Pada Pt.Angkasa Pura II (Persero) Bandara Sultan Iskandar Muda Banda Aceh. Skripsi. Universitas Islam Negeri UIN Ar-Raniry Banda Aceh 